Article

\title{
Distribution of Actual Evapotranspiration over Qaidam Basin, an Arid Area in China
}

\author{
Xiaomei Jin *, Renhong Guo and Wei Xia
}

School of Water Resources and Environment, China University of Geosciences, Beijing 100083, China; E-Mails: grenhong@163.com (R.G.); wxia32@163.com (W.X.)

* Author to whom correspondence should be addressed; E-Mail: jinxm@cugb.edu.cn; Tel.: +86-10-8232-2281; Fax: +86-10-8232-1081.

Received: 30 October 2013; in revised form: 21 November 2013 / Accepted: 9 December 2013 / Published: 13 December 2013

\begin{abstract}
Evapotranspiration is a major loss flux of the water balance in arid and semi-arid areas. The estimation of actual evapotranspiration has significance for hydrological and environmental purposes. The Surface Energy Balance System (SEBS) algorithm was applied to estimate actual evapotranspiration in the Qaidam Basin and its eight hydrological sub-regions, Northwest China. There were 3,036 cloud-free and atmospherically corrected MODIS satellite images from 2001 to 2011 used in the SEBS algorithm to determine the actual evapotranspiration. The result indicated that the estimated annual actual evapotranspiration of the basin increased with time and the value varied from 72.7 to $182.3 \mathrm{~mm}$. SEBS estimates were $7.5 \%$ and $14.1 \%$ of observed pan evaporation over the western and eastern areas, respectively. The variation of SEBS actual evapotranspiration is influenced by climate factors, vegetation, net radiation, land cover type and water table depth. The analysis of the evaporative behavior of different land cover types in the basin presented that water bodies, marsh, and farmland had relatively higher mean actual evapotranspiration though these land cover types make up less than $3.5 \%$ of the total basin. Bare soil has very low evapotranspiration and covered almost $60 \%$ of the study area. The actual evapotranspiration was observed to be decreased with an increase of water table depth. Overall, the SEBS algorithm proved to be useful and has potential for estimating spatial actual evapotranspiration on a regional scale.
\end{abstract}

Keywords: evapotranspiration; SEBS; vegetation; land cover type; water table depth 


\section{Introduction}

Evapotranspiration (ET) is the main part of water balance and plays an important role in the hydrological process. The surface ET on a regional scale can substantially influence the amount and spatial distribution of water resources. In an arid inland basin, ET is the major loss variable in water budget. It varies with land surface and local meteorological conditions, and it is difficult to be quantified [1]. Therefore, quantitative estimation of surface ET is essential for understanding the hydrological cycle, water management, and sustainable utilization of water resources [2-5].

Qaidam Basin is an inland basin rich in mineral resources in northwestern China. However, the basin is a water shortage area due to a dry climate and fast economic development. Sustainable development of Qaidam Basin will mostly depend on the efficient utilization and strict management of water resources, which require a relatively accurate estimation of ET on a regional scale.

The ET estimation based on remote sensing techniques has developed rapidly since thermal infrared data was first used for evapotranspiration prediction [6]. With the advantage of frequent updates and large area coverage, the remote sensing data has been used for ET estimation in many approaches [7-9]. The satellite images can provide regional scale land surface information effectively and can be used to estimate ET through a remote sensing method without quantifying other hydrological parameters [10]. Since ET cannot be measured directly by remote sensing, some models of indirect estimation of ET have been proposed for quantifying the energy balance parameters such as net radiation, soil heat flux, sensible heat flux, and then ET estimation [11-15]. Based on Gowda et al. [16] and Kalma et al. [17], the evapotranspiration estimation models using satellite data can be divided into two classes: (1) Semi-physical or physical approaches; (2) Empirical relationships for estimation of evapotranspiration. As Kustas and Anderson [18] stated, the physically based surface energy balance (SEB) models, especially SEBS, are less site-specific and require little subjective intervention, as opposed to techniques requiring the selection of hot and cold endpoints in the scene $[14,19,20]$. Sun et al. $[21,22]$ further put forward a simplified land surface model to calculate ET using the parameters estimated by a new stationarity-based method which couples the energy balance and water. The parameter estimated by the stationarity-based method can avoid calibration with field observation ET and can be applied broadly in a harsh area which has no continuous forcing (precipitation and radiation) and surface states (soil moisture and temperature). These physical models can also be served as a useful tool when time series of evapotranspiration is needed.

Physically based SEB models can be divided into single-source (e.g., SEBS, SEBAL) and two-source (e.g., TSEB) bulk transfer equations for sensible heat flux estimation [15,23]. Many studies have indicated that both single-source and two-source models can provide good results for the surface energy balance partitioning at different scales [24-26]. The single-source models were used relatively widely in hydro-meteorological fields due to their simplicity. For example, the SEBAL model can estimate actual ET by computing the different variables of the energy balance of the land surface [27-29]. The modified single-source models such as SEBS can adjust the differences between aerodynamic and radiometric surface temperatures in partial vegetation cover by employing physical models of soil-canopy heat exchange instead of separation of canopy and soil as two source terms [30]. Further, the modified surface energy budget technique can also be applied to map the distribution of lake evaporation and wetland ET [31]. 
The final aim of deriving the evapotranspiration by remote sensing is to reach good operational application under different land cover conditions [32,33]. The SEBS model has been validated in operational utility of evapotranspiration deriving for sparsely vegetated and dry areas [34,35], and thus it was selected as the main method for regional evapotranspiration estimation in this study.

The main objective of this study is to estimate the ET of the Qaidam Basin in the Tibet Plateau and to discuss its controlling factors. The specific objectives are: (1) to estimate the $\mathrm{ET}_{\mathrm{a}}$ of the Qaidam Basin using MODIS land products; (2) to discuss the controlling factors of regional $\mathrm{ET}_{\mathrm{a}}$, such as climate factors, vegetation, land cover types, and water table depth.

\section{Study Area}

Qaidam Basin stands between $34^{\circ} 40^{\prime} \mathrm{N}$ and $39^{\circ} 20^{\prime} \mathrm{N}$ and $90^{\circ} 00^{\prime}-99^{\circ} 20^{\prime} \mathrm{E}$ located in the northern part of Tibet Plateau, China. The total area is $276,233 \mathrm{~km}^{2}$ and the plain area covers $152,393 \mathrm{~km}^{2}$. The basin is typically classified as a continental arid climate, where the annual precipitation spatially varies between 16 and $190 \mathrm{~mm}$ from west to east and is concentrated from April to November. The annual pan evaporation ranges from 1,974 to $3,183 \mathrm{~mm}$ and significantly exceeds the annual precipitation. The annual mean air temperature is $4.77{ }^{\circ} \mathrm{C}$ in the center of the basin, while it is $1.53{ }^{\circ} \mathrm{C}$ at the boundary of the basin. The Qaidam Basin is a plateau basin and the elevation varies between 2,652 and $6,600 \mathrm{~m}$ (Figure 1).

Figure 1. Location of Qaidam Basin and eight hydrological sub-regions. The black points represent the meteorological stations and the black solid lines are the boundary of hydrological sub-regions.

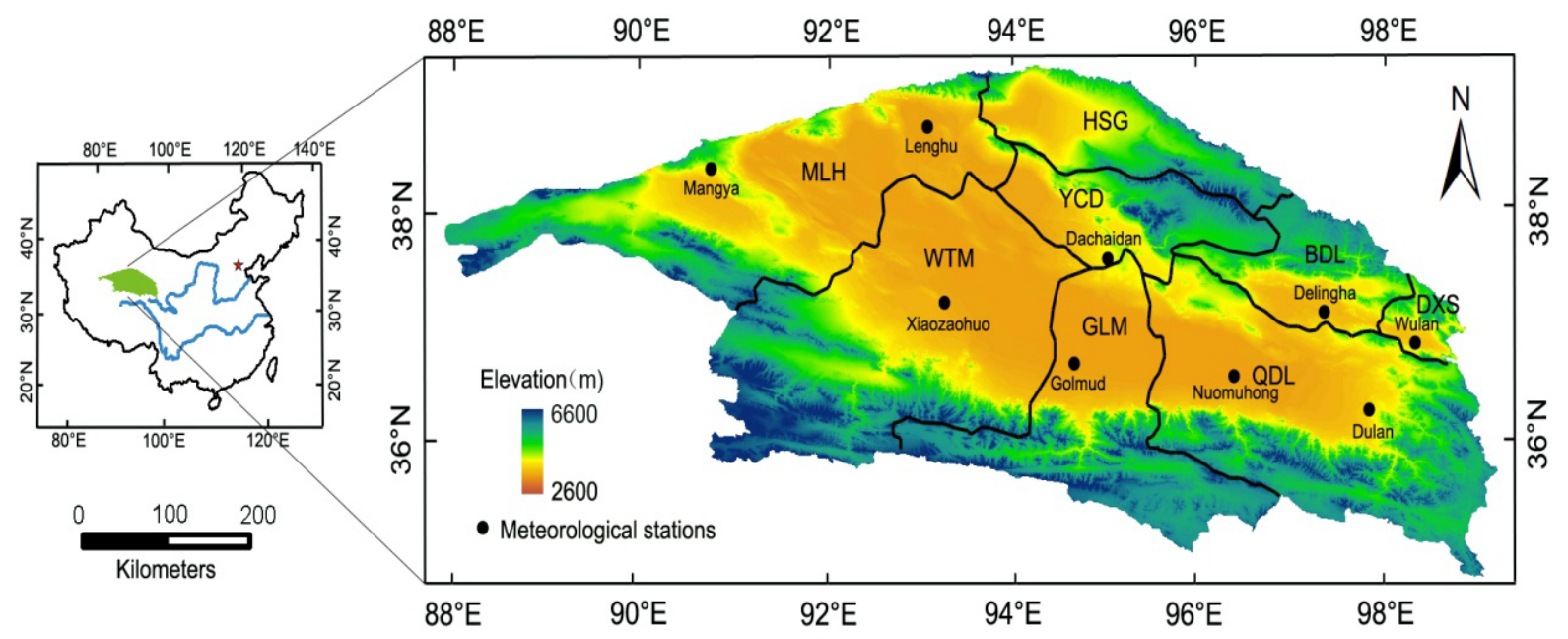

Spatially, most of the plain area of Qaidam Basin is desert and the alpine zone surrounds the plain. The plain area of the basin is dominated by sand covered with xeric plants such as Artemisia desertorum, Phragmites australis, Calligonum mongolicunl, Tamarix ramossissima Ledeb, Nitraria Schoberi L. and Achnatherum splendens. The alpine meadow is mainly distributed in the mountainous area around the Qaidam Basin. Sixty-four lakes are distributed in the basin and they receive recharge from streams and groundwater. The evapotranspiration is a major loss of the lake in the plain area. With 48 salt lakes distributed in the area, the basin is rich in salt, oil and coal minerals. 
The amount of available surface runoff of Qaidam Basin is approximately $49.6 \times 10^{8} \mathrm{~m}^{3}$ and the workable reserves of groundwater about $17 \times 10^{8} \mathrm{~m}^{3}$. However, the water resources are very unevenly distributed in space and time around Qaidam Basin. With the development of agriculture and industry, the water consumption increases and results in water shortage in irrigation. Considering the administrative divisions and the integrity of river systems, the Qaidam Basin is made up of eight hydrological sub-regions (Figure 1). The eight hydrological sub-regions and their areas are shown in Table 1.

Table 1. Areas and abbreviations of hydrological sub-regions in the Qaidam Basin.

\begin{tabular}{ccc}
\hline Hydrological Sub-Regions & Area $\mathbf{( k m}^{\mathbf{2}}$ & Abbreviation \\
\hline Mangya-Lenghu area & 56,194 & MLH \\
Harteng-Suganhu area & 20,137 & HSG \\
Yuqia -Chaidam area & 18,598 & YCD \\
Bayin-Delingha area & 16,119 & BDL \\
Dulan-Xisai area & 4,642 & DXS \\
Nalinggele-Wutumeiren area & 65,378 & WTM \\
Golmud area & 36,098 & GLM \\
Qaidam-Dulan area & 59,067 & QDL \\
\hline
\end{tabular}

\section{Material and Methods}

\subsection{Surface Energy Balance System Algorithm}

The SEBS algorithm, developed by $\mathrm{Su}$ [15], can be used to determine turbulent heat fluxes by employing satellite and meteorological data. It consists of: (1) an estimation of a series of land surface physical parameters, such as emissivity, albedo, vegetation coverage etc. based on spectral reflectance and radiance [36]; (2) an extended model of roughness length estimation for heat transfer [25]; (3) an evaporative fraction estimation at limiting cases by energy balance. Three parts of information are required to be input in SEBS model. The first part is the land surface physical parameters, such as emissivity, albedo, temperature, vegetation coverage fraction, leaf area index and roughness height. The second part consists of climate factors of air temperature, air pressure, relative humidity and wind speed. The third part includes measured downward solar radiation and downward longwave radiation.

The basic surface energy balance equation can be expressed as:

$$
R_{n}=G_{0}+H+L E
$$

where $R_{n}$ is the net radiation, $G_{0}$ is the soil heat flux, $H$ is the turbulent sensible heat flux, and $L E$ is the turbulent latent heat. Net radiation, $R_{n}$, can be calculated by:

$$
R_{n}=(1-\alpha) R_{s w d}+\varepsilon R_{l w d}-\varepsilon \sigma T_{0}^{4}
$$

where $\alpha$ is the albedo, $R_{s w d}$ and $R_{l w d}$ are the downward shortwave and longwave solar radiation $\left(\mathrm{W} \cdot \mathrm{m}^{-2}\right)$, respectively, $\varepsilon$ is the surface emissivity, $\sigma$ is the Stefan-Bolzmann constant $\left(5.67 \times 10^{-8} \mathrm{~W} \cdot \mathrm{m}^{-2} \cdot \mathrm{K}^{-4}\right)$, and $T_{0}$ is the surface temperature $(\mathrm{K}) . R_{s w d}$ and $R_{l w d}$ are estimated by meteorological measurement. $\alpha, \varepsilon$ and $T_{0}$ are physical parameters and can be obtained from remote sensing data.

The soil heat flux, $\mathrm{G}_{0}$, which is energy entering into the soil, can be estimated as follows: 


$$
G_{0}=R_{n}\left(\Gamma_{c}+\left(1-f_{c}\right)\left(\Gamma_{s}-\Gamma_{c}\right)\right)
$$

where $\Gamma_{c}$ and $\Gamma_{s}$ are empirical coefficients. $\Gamma_{s}$ is 0.315 for most bare soil condition [37] and $\Gamma_{c}$ is commonly taken as 0.05 for full vegetation [38]. The fractional canopy coverage $f_{c}$ would be used as an interpolation between these cases and it can be determined by the scaled Normalized Difference Vegetation Index (NDVI) as:

$$
f_{c}=\frac{N D V I-N D V I_{\min }}{N D V I_{\max }-N D V I_{\min }}
$$

where $N D V I_{\max }$ and $N D V I_{\min }$ are the NDVI for full vegetation $\left(f_{c}=1\right)$ and bare soil $\left(f_{c}=0\right)$, respectively.

In SEBS algorithm, the energy balance computation at limiting conditions would be used in order to derive the relative evaporation. At the dry limit, the sensible heat flux is at the maximum value, as well as evaporation would be zero because of limitation of soil moisture. The expression follows as:

$$
H_{d r y}=R_{n}-G_{0}
$$

At the wet limit, the sensible heat flux can be taken as the minimum value, and the ET is determined by the available energy in the given surface and the atmospheric conditions. It follows from the equation as:

$$
H_{\text {wet }}=R_{n}-G_{0}-L E_{\text {wet }}
$$

Based on above process, the relative evaporation can be derived as:

$$
\Lambda_{r}=1-\frac{H-H_{w e t}}{H_{d r y}-H_{w e t}}
$$

Finally, the evaporation fraction which is the energy used for the evapotranspiration process is estimated as:

$$
\Lambda=\frac{L E}{H+L E}=\frac{L E}{R_{n}-G_{0}}=\frac{\Lambda_{r} L E_{w e t}}{R_{n}-G_{0}}
$$

The basic formulation of SEBS algorithm is constituted by Equations (1-8) [15]. The daily evaporation can be estimated based on the assumption that evaporative fraction is approximately equal to the instantaneous value.

$$
E_{\text {daily }}=8.64 \times 10^{7} \times \frac{\Lambda \overline{R_{n}}}{L \rho_{w}}
$$

where $E_{\text {daily }}$ is the actual evaporation $\left(\mathrm{mm} \cdot \mathrm{d}^{-1}\right), \mathrm{L}$ is the latent heat of vaporization $\left(\mathrm{J} \cdot \mathrm{kg}^{-1}\right), \overline{R_{n}}$ is the daily net radiation and is $\rho_{w}$ the water density $\left(\mathrm{kg} \cdot \mathrm{m}^{-3}\right)$.

Roughness terms are used to characterize the land surface condition. Roughness height of heat transfer, $z_{\text {oh }}$, can be estimated from a model by Su et al. [25]. $k B^{-1}$ or excess resistance term is taken into account to determine momentum and heat transfer over different ground surfaces in one source model of SEBS [39]. $k B^{-1}$ is derived by:

$$
k B^{-1}=\frac{k C_{d}}{4 C_{t} \frac{u_{*}}{u(h)}\left(1-e^{-\frac{n_{e c}}{2}}\right)} f_{c}^{2}+2 f_{c} f_{s} \frac{k \cdot \frac{u_{*}}{u(h) \cdot \frac{z_{o m}}{h}}}{C_{t}^{*}}+k B_{s}^{-1} f_{s}^{2}
$$

where $f_{c}$ is the fractional canopy coverage and $f_{s}$ is fraction of non-vegetated soil $\left(1-f_{c}\right)$. $C_{d}$ is the drag coefficient of the foliage elements assumed to take the value of 0.2. $C_{t}$ and $C_{t}{ }^{*}$ are coefficients of heat 
transfer for a leaf and soil, respectively. $n_{e c}$ is the within-canopy wind speed profile extinction coefficient. $z_{o m}$ is the roughness length for momentum transfer. The term of $k B_{s}^{-1}$ is used for bare soils and was formulated by Brutsaert [40]. The roughness height, $z_{o h}$ is determined from:

$$
z_{o h}=\left(\frac{z_{o m}}{\exp \left(k B^{-1}\right)}\right)
$$

In this study, the daily ET values of the SEBS results were averaged for all pixels of the study area in each image and this mean value was considered to be the daily ET of the total Qaidam Basin. There was a total of 1,122,289 pixels in the study area. Because of cloud cover, there were only several cloud-free images available in one month to be used to estimate daily ET and the average ET of these days was represented the mean daily ET of this month. As a result, the monthly ET variables can be obtained based on mean daily ET by multiplying the number of days in a month and the summation yields the annual $\mathrm{ET}_{\mathrm{a}}$ of SEBS.

\subsection{Dataset}

\subsubsection{MODIS Data}

The MODIS satellite data were downloaded from the website of NASA's Earth Observing System Data and Information System. The satellite and solar zenith and azimuth angles were "unpacked" by MODIS Swath re-projection tool (MRTSwath) which is a standard operation. MODIS surface reflectance products (MOD09A1 product) and MODIS land surface temperature data (MOD11A2 product) were derived by monitoring the Earth's surface. MOD9 and MOD11 are based on eight-day composites and have spatial resolution of $500 \mathrm{~m}$ and 1,000 m, respectively. 1-7 bands of MOD09 and 31, 32 bands of MOD11 were selected. In this study, 3,036 cloud-free MODIS images covered the Qaidam Basin in different months of the 11 years from 2001 to 2011 and were used to estimate the evapotranspiration in regional scale. The numbers of available image composites for total basin were 46 per year after mosaicking. All the images were resampled to $500 \mathrm{~m}$ resolution with the Nearest Neighborhood method to match spatial resolution of spectral reflectance bands.

MODIS NDVI data (MOD13A1), which is generated by daily MODIS Level-2G surface reflectance and has been corrected for ozone absorption, aerosols and molecular scattering, can depict spatial and temporal variation of vegetation activities. With $250 \mathrm{~m}$ spatial resolution, the MODIS NDVI data has been used in a wide range of researches, such as drought monitoring, global vegetation variation, agricultural and hydrologic modeling [41-48]. Since June, July, August and September are the most productive seasons for vegetation growth during a year in Northwest China, 88 MODIS NDVI images of 16-day composites of June, July, August and September from the year 2001 to 2011 were used for illustrating the long-term variation of vegetation in the Qaidam Basin.

\subsubsection{GLDAS}

GLDAS (the Global Land Data Assimilation System) drives multiple, offline (not coupled to the atmosphere) land surface models, integrates a huge quantity of observation based data, and executes globally at high resolutions $\left(2.5^{\circ}\right.$ to $\left.1 \mathrm{~km}\right)$, enabled by the Land Information System (LIS) [49]. The temporal resolution of the GLDAS products is three-hourly, and monthly products are also generated 
through temporal averaging of the three-hourly products. Currently, GLDAS drives four land surface models (LSMs): Mosaic, Noah, the Community Land Model (CLM), and the Variable Infiltration Capacity (VIC). GLDAS bands 19-22 to specific humidity $\left(\mathrm{kg} \cdot \mathrm{kg}^{-1}\right)$, wind speed $\left(\mathrm{m} \cdot \mathrm{s}^{-1}\right)$, air temperature $(\mathrm{K})$, and air pressure $(\mathrm{Pa})$, respectively, were selected in this study. In total, 132 Sets of Monthly GLDAS products at a spatial resolution of 0.25 degree over the Qaidam Basin from the year 2001 to 2011 were used to estimate evapotranspiration. The GLDAS data was resampled and interpolated to have the same spatial resolution as the ready-processed MODIS data.

\subsubsection{Meteorological Observation Data}

The corresponding meteorological dataset of air temperature, precipitation, relative humidity, wind speed and pan observed evaporation to the remote sensing data in 8 meteorological stations (Mangya, Lenghu, Xiaozaohuo, Dachaidan, Delingha, Golmud, Nuomuhong, Dulan, Wulan) was used in this study (Figure 1). The monthly average precipitation, air temperature, relatively humidity and wind speed of these eight stations during the period of 2001 to 2011 were available in Qaidam Basin. However, only monthly pan evaporation from 2006 to 2009 data were collected and subsequently measured by E601 dish. The maximum elevation is 3,950 $\mathrm{m}$ for Wulan station with a minimum of $2,767 \mathrm{~m}$ in Xiaozaohuo station. The yearly net radiation of Golmud station from 2001 to 2011 was used in analysis of its impact on ET.

Conversion coefficient of evaporation was defined as the ratio of actual evapotranspiration to observed pan evaporation in this study. The regional actual evapotranspiration plays a very important role in the hydrological cycle and groundwater modeling. However, due to inconvenient transportation and a lower population in Northwestern China, there is little field measurement data of evaporation except the pan observations in meteorological stations. Therefore, the conversion coefficient of evaporation has a significant effect on estimation of actual evapotranspiration and depends mostly on the empirical formulation in these areas. In this study, the correlation between the SEBS actual $\mathrm{ET}_{\mathrm{a}}$ and the pan observations was established to find the conversion coefficient of evaporation.

\subsubsection{Water Table Depth}

Water table depth is a factor that can influence actual evapotranspiration at a site. The relationship between $\mathrm{ET}_{\mathrm{a}}$ and water table depth reflects the evaporation behavior to groundwater depth. Field measurements of groundwater level in the Qaidam Basin were investigated at WTM and DXS sub-regions during June 2011. Groundwater levels in most of the sites were measured in wells as shown in Figure 2. Consequently, the number of groundwater level measurements in the WTM sub-region is 133 with a number of 107 in the DXS sub-region. The contour maps of water table depth in these two areas were constructed by interpolating field measurements to the same resolution grid as the MODIS data. In most parts of the DXS area, the water table depth is less than $8 \mathrm{~m}$, and the depth in the WTM area is smaller than $3 \mathrm{~m}$. Therefore, $3 \mathrm{~m}$ and $10 \mathrm{~m}$ can be considered the limit of the water table depth in these two areas, respectively.

For correlation analysis with $\mathrm{ET}_{\mathrm{a}}$, the contour map of the water table depth was graded to the same $500 \mathrm{~m}$ resolution grid as the MODIS data using the arithmetic mean. The new water table depth map 
matches the $\mathrm{ET}_{\mathrm{a}}$ map. For each grid cell, a pair of $\mathrm{ET}_{\mathrm{a}}$ and water table depth values can be read. There are in total 4,833 and 8,244 pairs of $\mathrm{ET}_{\mathrm{a}}$ and water table depth in WTM area and DXS area, respectively.

The range of water table depth from 0 to $8 \mathrm{~m}$ in DXS was divided into a total of 80 intervals with $0.1 \mathrm{~m}$ in each interval. In each interval the corresponding daily actual evapotranspiration values in June 2011 were averaged. The mean values represent the general conditions of the actual evapotranspiration in different water table depth. The same above program was also applied in WTM area.

Figure 2. Distribution of groundwater observation wells in WTM and DXS sub-regions.

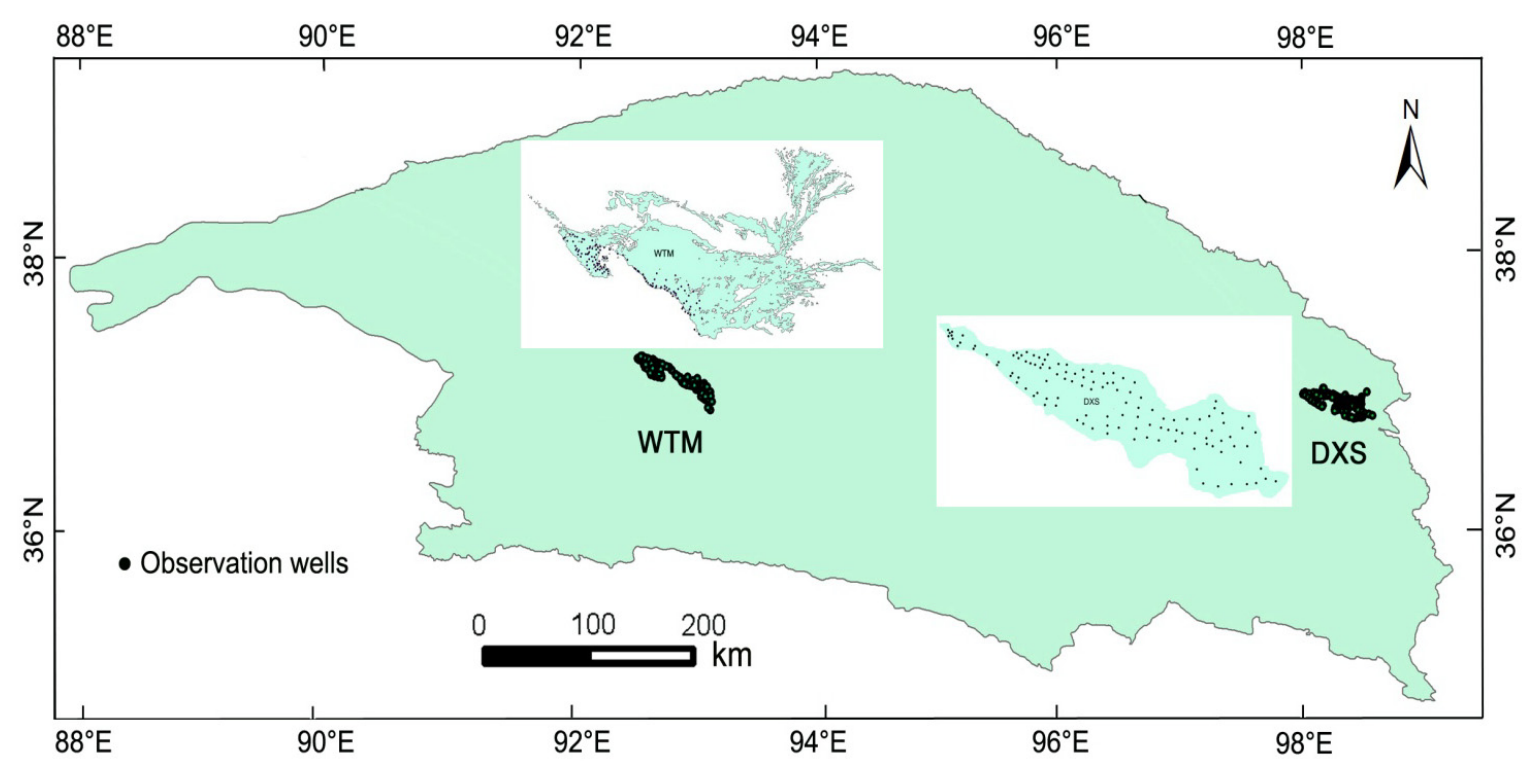

\section{Results}

\subsection{Spatial and Temporal Distribution of Actual Evapotranspiration by SEBS}

The spatial distribution of mean daily $\mathrm{ET}_{\mathrm{a}}$ by SEBS model in eight sub-regions of Qaidam Basin is illustrated in Figure 3 for 11 years. The mean estimated daily $\mathrm{ET}_{\mathrm{a}}$ over the total basin varies from 0 to $3.2 \mathrm{~mm} \cdot \mathrm{d}^{-1}$. The areas with higher mean daily $\mathrm{ET}_{\mathrm{a}}$ are lakes and vegetated areas and the mean $\mathrm{ET}_{\mathrm{a}}$ in these areas ranges from 1.7 to $2.5 \mathrm{~mm} \cdot \mathrm{d}^{-1}$. The western and northern parts of Qaidam Basin are dominated by desert where the daily $\mathrm{ET}_{\mathrm{a}}$ varies from 0 to $0.7 \mathrm{~mm} \cdot \mathrm{d}^{-1}$. The eastern and southern parts of Qaidam Basin are mainly covered by shrubs and alpine meadows, which have relatively higher actual evapotranspiration. The SEBS modeled annual ET $\mathrm{F}_{\mathrm{a}}$ in Qaidam Basin and its eight hydrological sub-regions from 2001 to 2011 are shown in Table 2.

In Table 2 it can be noted that the maximum estimated annual $\mathrm{ET}_{\mathrm{a}}$ by SEBS is $266.8 \mathrm{~mm}$ in 2011 over DXS sub-regions, and the lowest $\mathrm{ET}_{\mathrm{a}}$ estimate is $139.0 \mathrm{~mm}$ in WTM areas. The areas with higher estimated $\mathrm{ET}_{\mathrm{a}}$ in Qaidam Basin are GLM and QDL sub-regions where the east parts are located and the annual $\mathrm{ET}_{\mathrm{a}}$ of 2011 are $227.4 \mathrm{~mm}, 239.3 \mathrm{~mm}$, respectively. The lower annual $\mathrm{ET}_{\mathrm{a}}$ areas are MLH and YCD sub-regions in west parts of Qaidam Basin and the annual $\mathrm{ET}_{\mathrm{a}}$ values are $145.9 \mathrm{~mm}$, $165.7 \mathrm{~mm}$, respectively. 
Figure 3. Spatial distribution of mean daily SEBS ET $_{a}$ during the period of 2001-2011. (a) 2001, (b) 2002, (c) 2003, (d) 2004, (e) 2005, (f) 2006, (g) 2007, (h) 2008, (i) 2009, (j) 2010 and (k) 2011 .

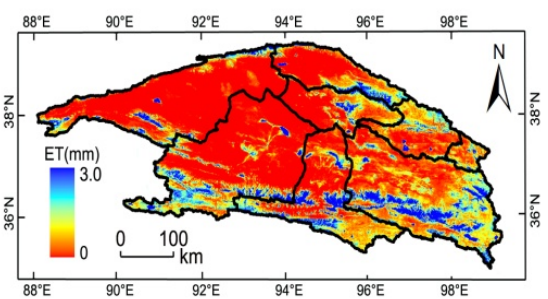

(a)

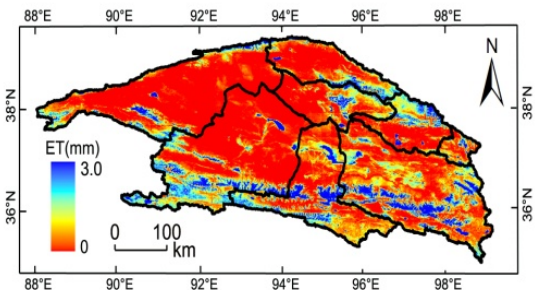

(c)

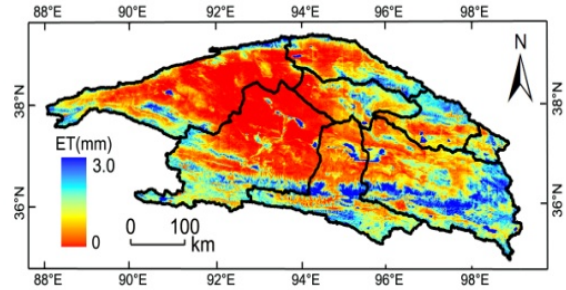

(e)

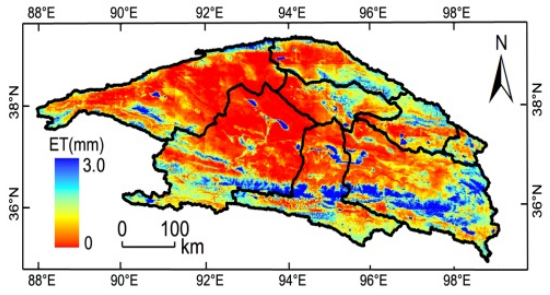

(g)

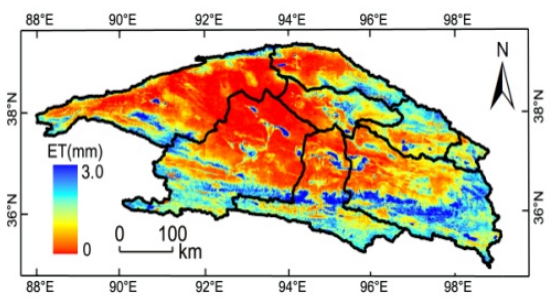

(i)

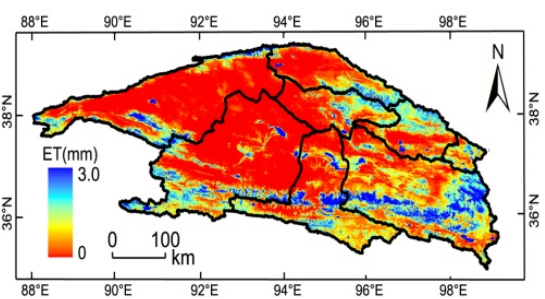

(b)

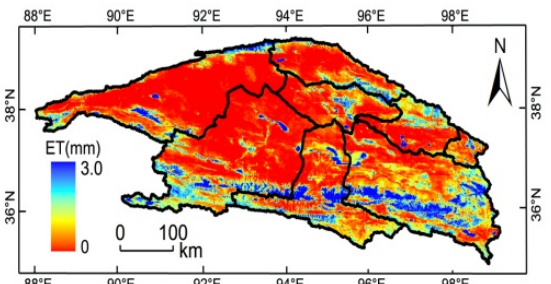

(d)

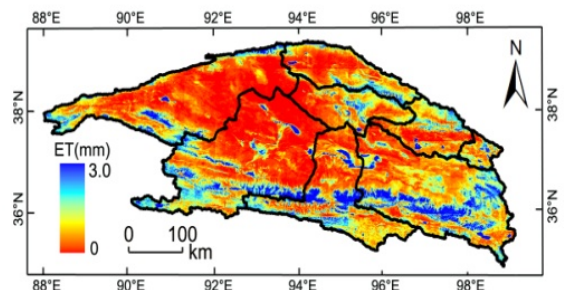

(f)

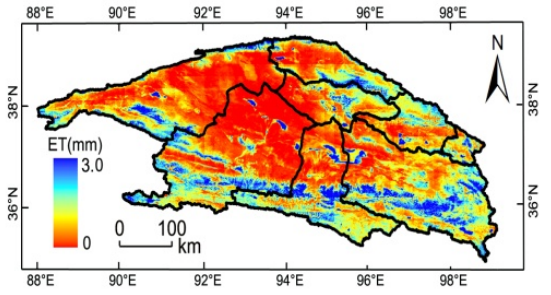

(h)

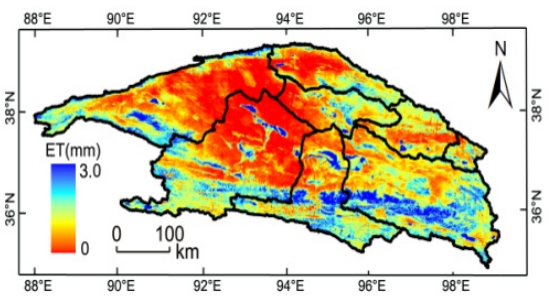

(j)

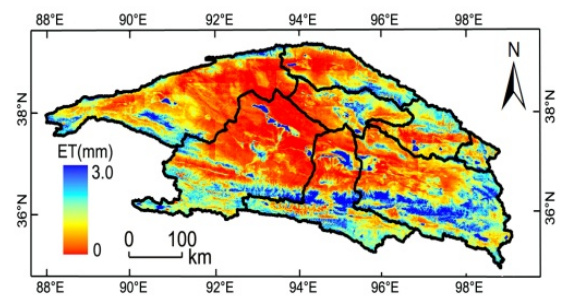

(k) 
Table 2. Annual SEBS $\mathrm{ET}_{\mathrm{a}}(\mathrm{mm})$ of total basin and eight hydrological sub-regions from 2001 to 2011.

\begin{tabular}{cccccccccc}
\hline Year & Total Basin & MLH & HSG & YCD & BDL & DDDXS & WTM & GLM & QDL \\
\hline 2001 & 72.7 & 35.9 & 75.9 & 61.6 & 77.1 & 94.6 & 54.0 & 97.9 & 114.1 \\
2002 & 73.9 & 46.5 & 74.0 & 66.5 & 90.8 & 115.1 & 51.1 & 86.0 & 115.5 \\
2003 & 78.1 & 44.2 & 76.3 & 71.4 & 92.9 & 97.1 & 70.6 & 106.7 & 100.6 \\
2004 & 84.5 & 51.0 & 78.4 & 64.4 & 75.7 & 97.9 & 69.4 & 113.6 & 127.9 \\
2005 & 143.9 & 95.3 & 149.2 & 136.7 & 182.8 & 222.3 & 98.1 & 176.6 & 210.1 \\
2006 & 123.2 & 86.5 & 118.9 & 109.4 & 119.9 & 162.9 & 103.4 & 155.9 & 166.9 \\
2007 & 135.1 & 89.9 & 148.6 & 124.4 & 158.8 & 199.9 & 103.2 & 164.8 & 185.9 \\
2008 & 144.8 & 107.4 & 158.9 & 133.1 & 155.3 & 205.7 & 115.6 & 173.8 & 190.5 \\
2009 & 170.1 & 113.7 & 167.9 & 160.3 & 222.9 & 260.0 & 144.3 & 210.3 & 238.5 \\
2010 & 169.2 & 134.9 & 143.5 & 149.3 & 153.3 & 199.9 & 132.7 & 220.3 & 232.9 \\
2011 & 182.3 & 145.9 & 175.9 & 165.7 & 195.9 & 266.8 & 139.0 & 227.4 & 239.3 \\
\hline
\end{tabular}

\subsection{Long-Term Change of Annual Actual Evapotranspiration}

Figure 4 presents the increase of SEBS annual $\mathrm{ET}_{\mathrm{a}}$ in $\mathrm{mm}$ during the period 2001-2011 over Qaidam Basin and the eight sub-regions. Overall, the annual SEBS ET $\mathrm{a}_{\mathrm{a}}$ of the basin is increased with time and the value varies from 72.7 to $182.3 \mathrm{~mm}$ with the rate of $6.25 \mathrm{~mm}$ per year (the bold black line).

Figure 4. Variation of annual SEBS $\mathrm{ET}_{\mathrm{a}}$ of eight hydrological sub-regions and the total basin during the period of 2001-2011.

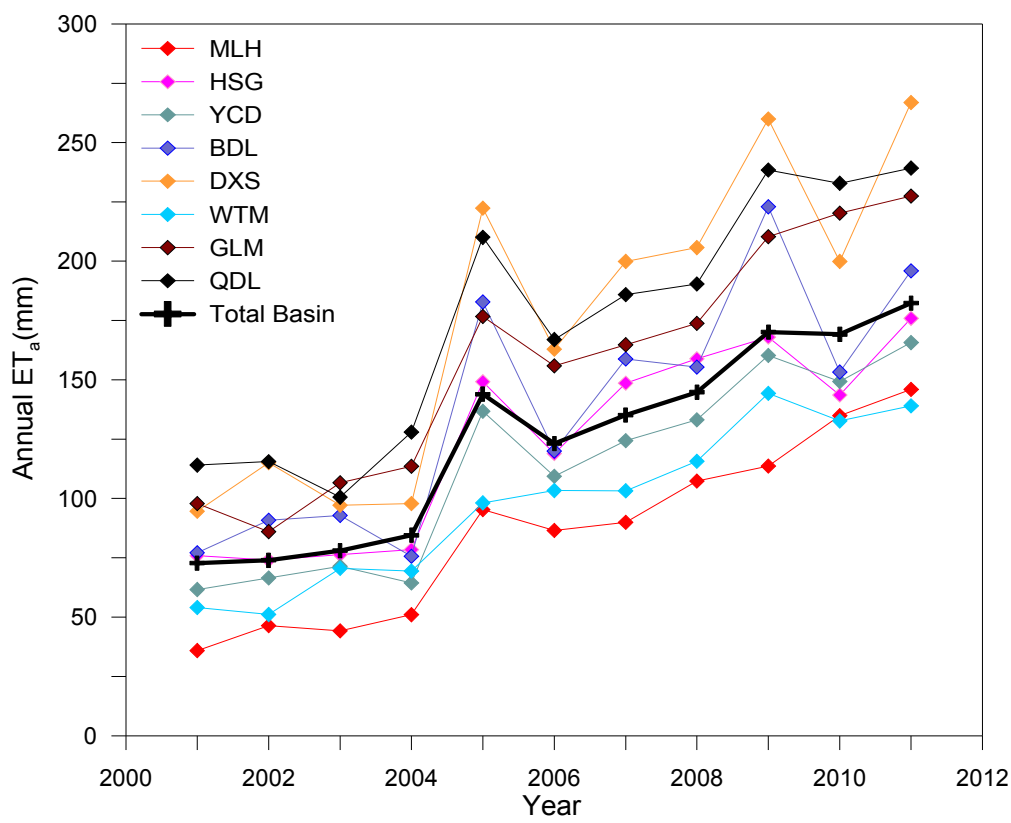

It can be seen that the annual actual $\mathrm{ET}_{\mathrm{a}}$ of all eight sub-regions increased with time and approximately achieved its biggest increase from the year 2005. Although the minimum and maximum values of actual $\mathrm{ET}_{\mathrm{a}}$ were different, the rate of increase was more or less the the same. Compared with the other sub-regions, the actual $\mathrm{ET}_{\mathrm{a}}$ of MLH, WTM and YCD (the red, cyan and green lines) 
sub-regions in the western part of the basin were the smallest because of sparse vegetation and very little precipitation. QDL, BDL, DXS and GLM sub-regions (the black, purple, orange and brown lines) in the eastern part of Qaidam Basin presented relative high vegetation cover and thus had higher values of actual $\mathrm{ET}_{\mathrm{a}}$.

\subsection{Conversion Coefficient of Evaporation}

The observed pan evaporation of seven meteorological stations (Lenghu, Xiaozaohuo, Dachaidan, Golmud, Nuomuhong, Wulan and Dulan) from 2006 to 2009 are available and are used for estimation of the conversion coefficient of evaporation. Since the annual precipitation increases from the western to the eastern area, which is same as the variation of estimated $\mathrm{ET}_{\mathrm{a}}$ by SEBS, the Qaidam Basin is divided into two parts for estimation of conversion coefficient between SEBS $\mathrm{ET}_{\mathrm{a}}$ and pan observations. Lenghu, Dachaidan and Xiaozaohuo stations were selected for west area as Golmud, Nuomuhong, Wulan and Dulan stations were considered as the analysis in eastern regions.

Figure 5a presents the correlation of yearly estimated SEBS ET $\mathrm{a}_{\mathrm{a}}$ with corresponding observed pan evaporation of Lenghu, Dachaidan and Xiaozaohuo stations in the western part of Qaidam Basin. The $\mathrm{R}$-square is 0.69 and the evaporation coefficient is 0.075 . It means the $\mathrm{SEBS} \mathrm{ET}_{\mathrm{a}}$ is $7.5 \%$ of observed pan evaporation.

Figure 5. Correlation between $\mathrm{SEBS} \mathrm{ET}_{\mathrm{a}}$ estimates and observed pan evaporation in (a) MLH, YCD and WTM sub-regions (west areas) and (b) QDL, DXS, BDL, GLM sub-regions (east areas) of Qaidam Basin.

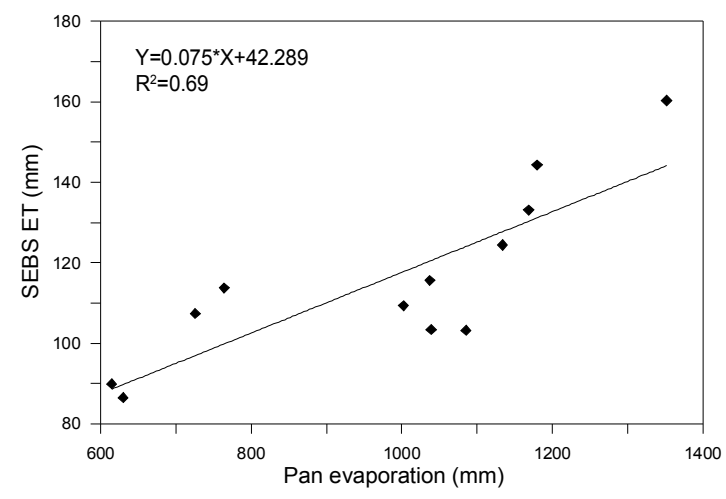

(a)

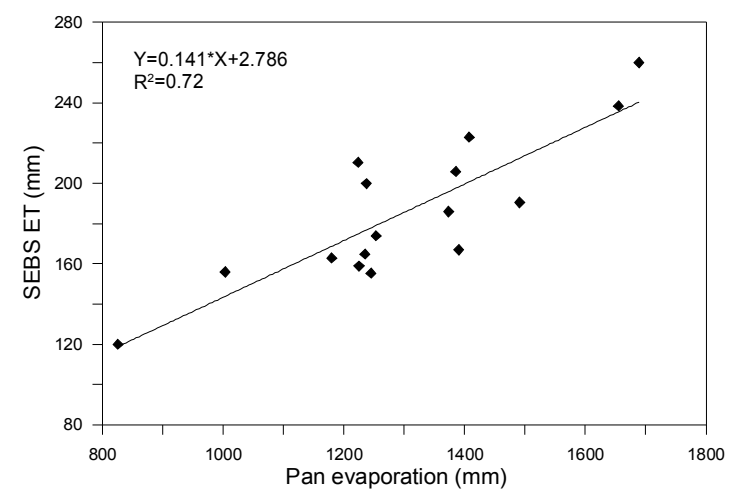

(b)

The correlation of yearly SEBS $\mathrm{ET}_{\mathrm{a}}$ with corresponding observed pan evaporation of Golmud, Nuomuhong, Dulan and Wulan stations in the eastern area of Qaidam Basin is illustrated in Figure 5b. The evaporation coefficient is 0.141 and the R-square is 0.72 .

\section{Discussion}

\subsection{Effect of Precipitation, NDVI and Net Radiation on Actual Evapotranspiration}

The increase of annual actual evapotranspiration can be understood by considering the variation about the annual precipitation, vegetation cover and net radiation. Figure 6 shows the increase of 
annual precipitation, mean NDVI and net radiation across Qaidam Basin. The annual precipitation ranged from 60 to $133 \mathrm{~mm}$, with the maximum being $154 \mathrm{~mm}$ in 2010 (Figure 6a). The big increase of precipitation from 2001 to 2005 resulted in a spike of actual evapotranspiration in 2005. NDVI is an index for monitoring the vegetation cover and it was increased gently after 2002 in Qaidam Basin. It varied between 0.127 and 0.165 with a maximum of 0.172 in 2010 (Figure $6 \mathrm{~b}$ ). The net radiation is the energy driver for ET change and the yearly net radiation ranged from 1,840 to $2,149 \mathrm{~W} \cdot \mathrm{J} \cdot \mathrm{m}^{-2}$ with the maximum of $2,343 \mathrm{~W} \cdot \mathrm{J} \cdot \mathrm{m}^{-2}$ in 2010 (Figure $6 \mathrm{c}$ ). The combined effect of precipitation, vegetation and net radiation resulted in increases of actual evapotranspiration. However, precipitation and vegetation are the dominant constraint factors of actual evapotranspiration in the Qaidam Basin. The $\mathrm{ET}_{\mathrm{a}}$ is very small in the dry and cool winter season (November, December, January and February) and it is mostly concentrated in spring, summer and autumn seasons. Higher precipitation and vegetation cover results in higher $\mathrm{ET}_{\mathrm{a}}$ in wet and hot seasons in the basin.

Figure 6. Variation of (a) annual precipitation, (b) NDVI and (c) net radiation during the period of 2001-2011 in Qaidam Basin.

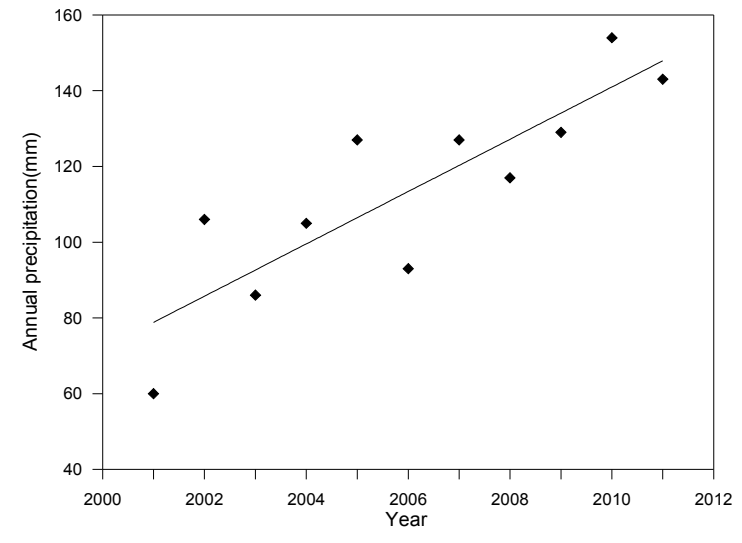

(a)

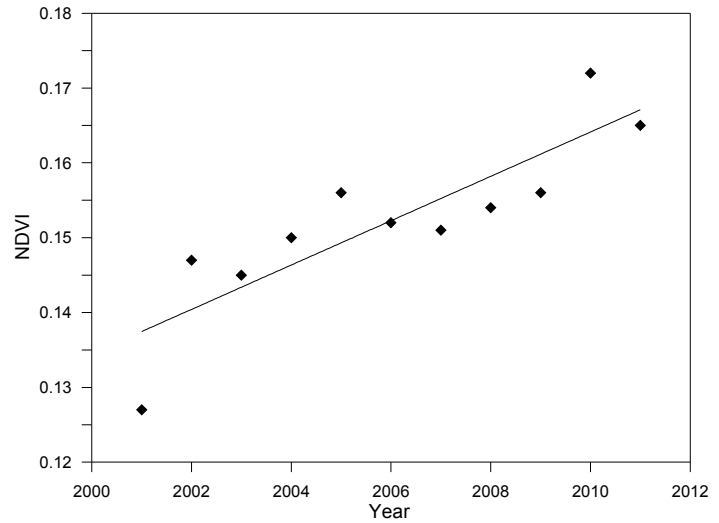

(b)

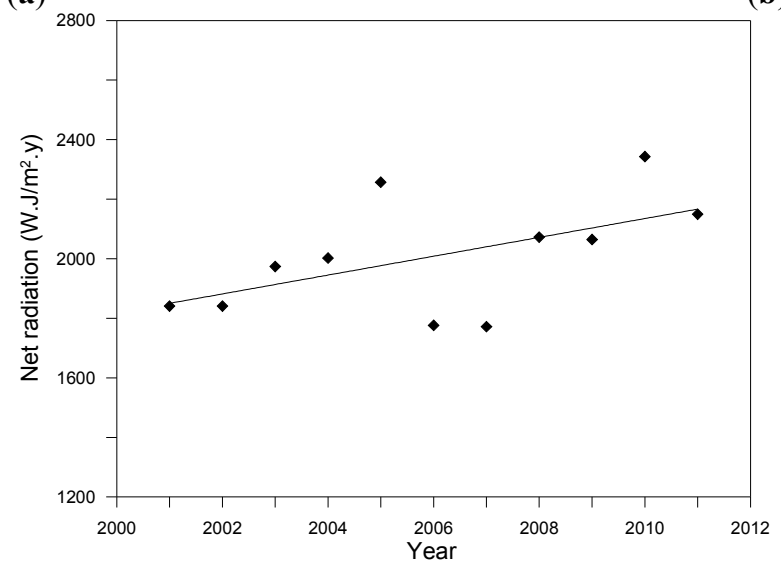

(c)

\subsection{Meteorological Factors and Actual SEBS Evapotranspiration}

Monthly precipitation, air temperature, relative humidity and wind speed were averaged, respectively, over eight meteorological stations (Lenghu, Dachaidan, Xiaozaohuo, Golmud, 
Nuomuhong, Delingha, Wulan and Dulan) in Qaidam Basin. Figure 7 shows the correlation of monthly SEBS $\mathrm{ET}_{\mathrm{a}}$ with corresponding monthly precipitation, air temperature, relative humidity and wind speed from 2001 to 2011. The result indicated that $\mathrm{SEBS}_{\mathrm{ET}} \mathrm{a}$ has a positive correlation with precipitation and air temperature; the R-square is 0.656 and 0.675 , respectively. On the other hand, the relative humidity and wind speed have little correlation with SEBS ET ; the R-square is 0.453 and 0.076 , respectively.

Figure 7. Correlation between (a) precipitation, (b) air temperature, relative humidity, (c) wind speed and (d) SEBS ET $\mathrm{a}_{\mathrm{a}}$.

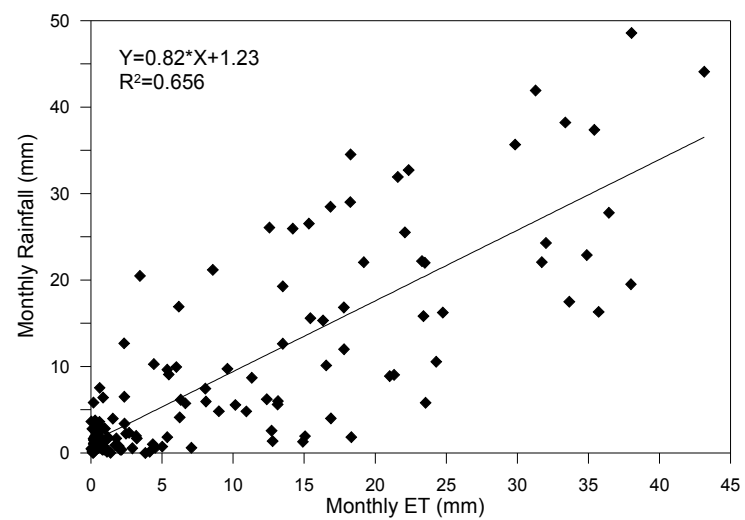

(a)

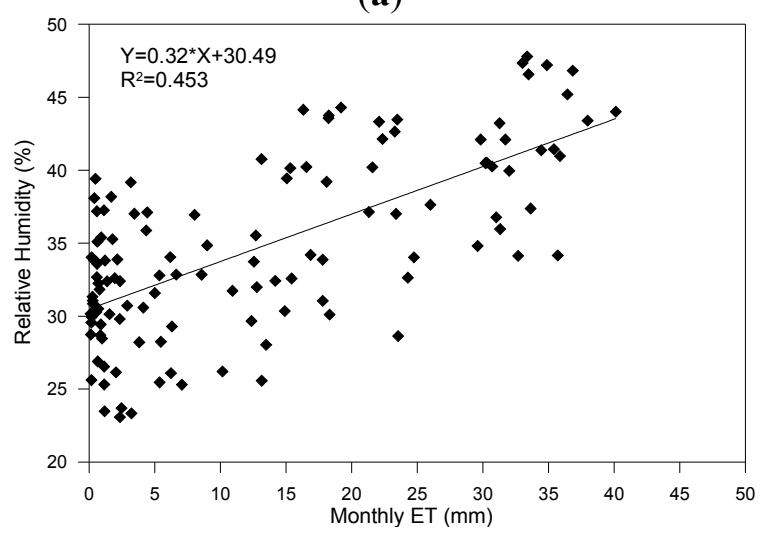

(c)

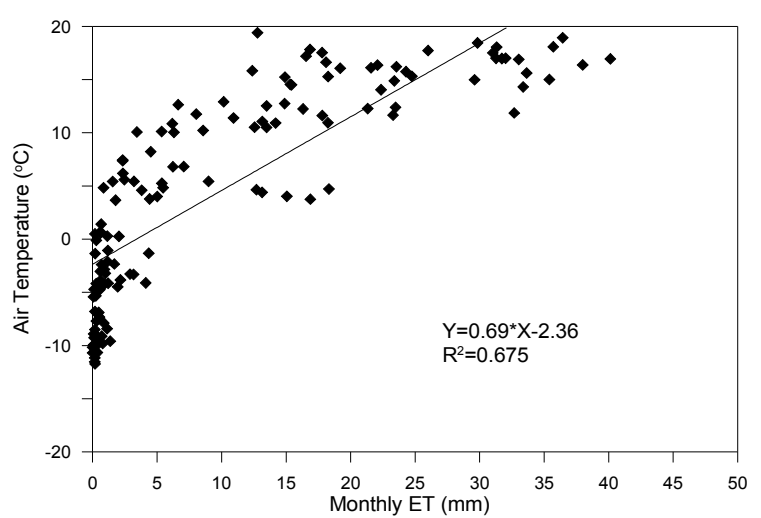

(b)

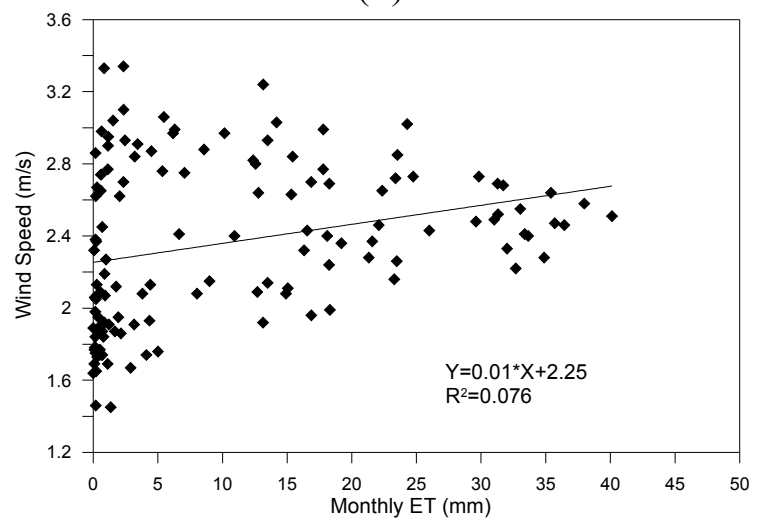

(d)

SEBS is highly sensitive to temperature in all input meteorological conditions [39]. Su [15] and Badola [50] also reported that SEBS is sensitive to the gradient of surface-air temperature. With the way SEBS is formulated, air temperature can affect the calculated value of sensible heat flux and further has a propagation effect on determination of latent heat flux.

\subsection{Vegetation and Actual SEBS Evapotranspiration}

Generally, the vegetation of Qaidam Basin is sparse and the vegetation cover fraction is very low. Vegetation is dominated by desert plants. As the depth to groundwater variation, low water table plants such as Artemisia desertorum will be changed into high water table plants such as Phragmites australis. Correspondingly, low salt tolerance vegetation such as Artemisia desertorum and 
Phragmites australis will be replaced by high salt tolerance vegetation such as Tamarix ramossissima Ledeb and Achnatherum splendens with the variation of soil salt content.

MODIS NDVI of June, July, August and September data were averaged to represent the vegetation condition of the Qaidam Basin. Figure 8 presents the variation of annual SEBS ET $\mathrm{a}$ and mean NDVI during the period of 2001-2011. The result indicated that the annual actual evapotranspiration was positively correlated with NDVI and the R-square is 0.67 .

Figure 8. Variation of annual SEBS ET $\mathrm{a}_{\mathrm{a}}$ and mean NDVI from 2001 to 2011.

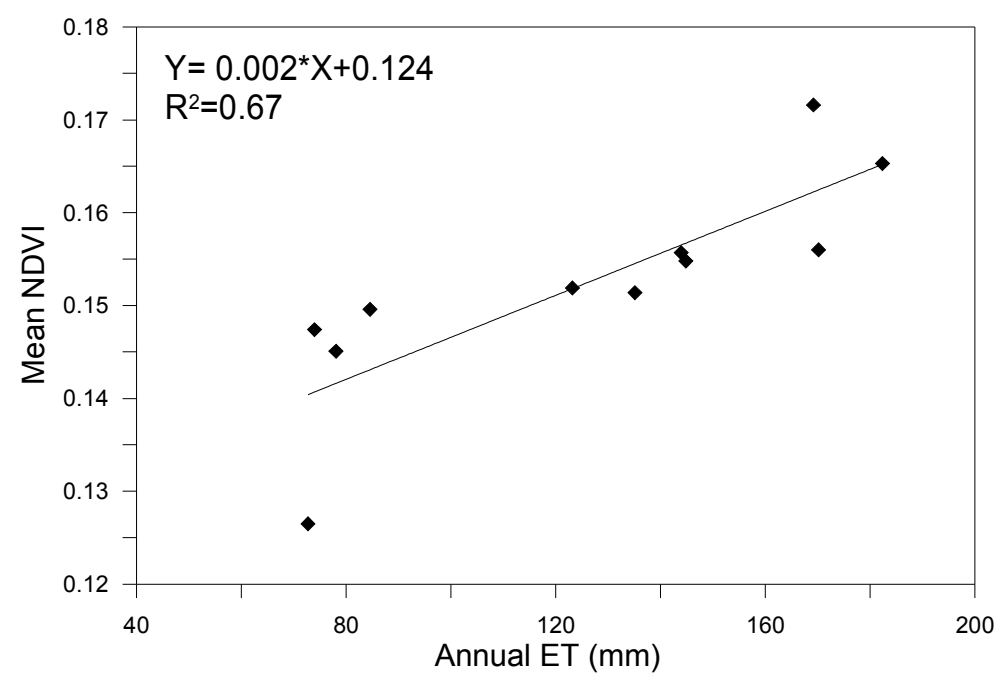

\subsection{Land Cover Type and Actual SEBS Evapotranspiration}

The land cover map used in this research is from a combination of MODIS NDVI of 2011 and field investigation (Figure 9). It is used in the analysis of the actual evapotranspiration of different land cover types in the Qaidam Basin.

Figure 9. Land cover and vegetation types of Qaidam Basin in 2011. The black solid line represents a section from north to south.

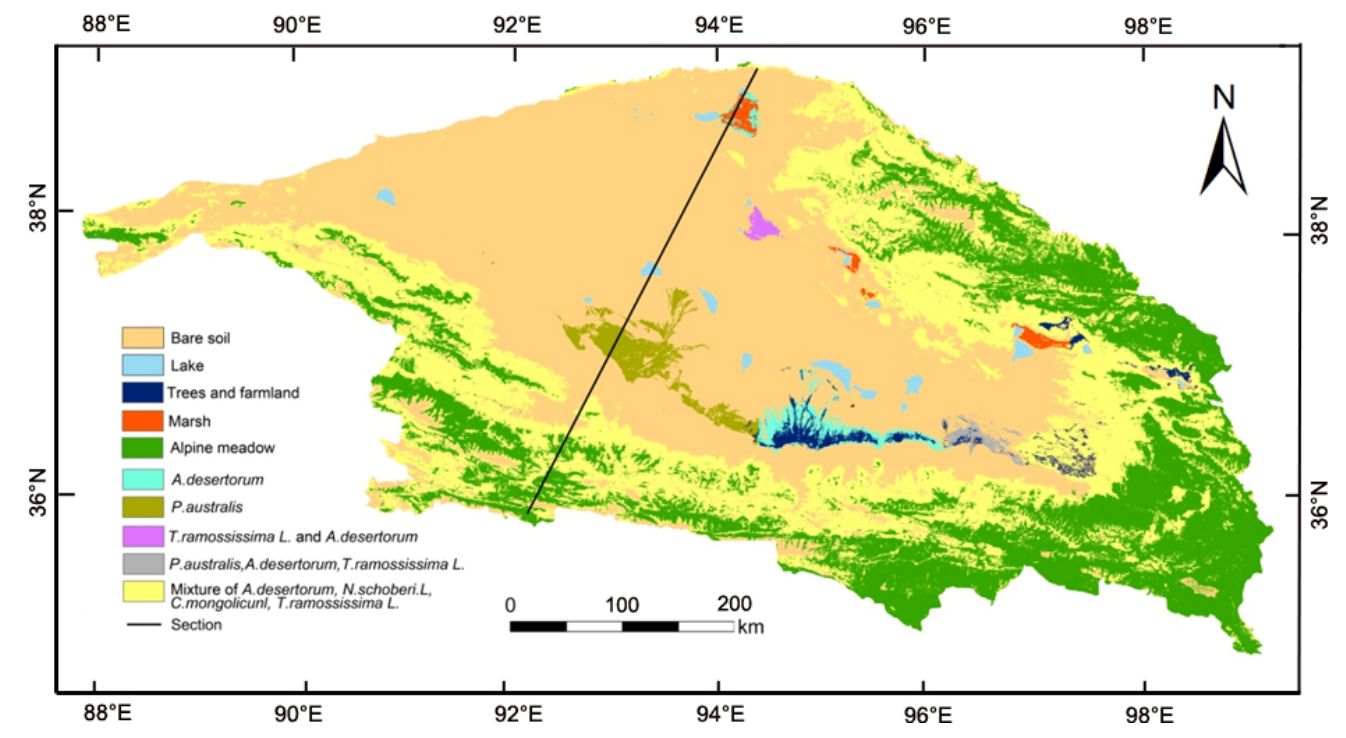


The variation of actual evapotranspiration across the basin is an index of the water consumption of existing land cover types. The long-term change of evapotranspiration or water use of the different land cover types in Qaidam Basin is analyzed by monthly SEBS $\mathrm{ET}_{\mathrm{a}}$ and the land cover map. The long-term variation of monthly SEBS $\mathrm{ET}_{\mathrm{a}}$ for different land cover types in Qaidam Basin are as shown in Figure 10. It can be noted in Figure 10 that the mean monthly actual evapotranspiration of all land cover types were increased with time. The monthly $\mathrm{ET}_{\mathrm{a}}$ of water bodies, mash, mixture of farmland/trees and shrubs had a relatively substantial increase since 2005. However, the $\mathrm{ET}_{\mathrm{a}}$ of bare soil had no significant change from 2001 to 2011. The variation of mean monthly $\mathrm{ET}_{\mathrm{a}}$ for different land cover types can be better understood by increases of precipitation and vegetation cover.

Figure 10. Monthly SEBS ET $\mathrm{a}_{\mathrm{a}}$ of different land cover types in Qaidam Basin.

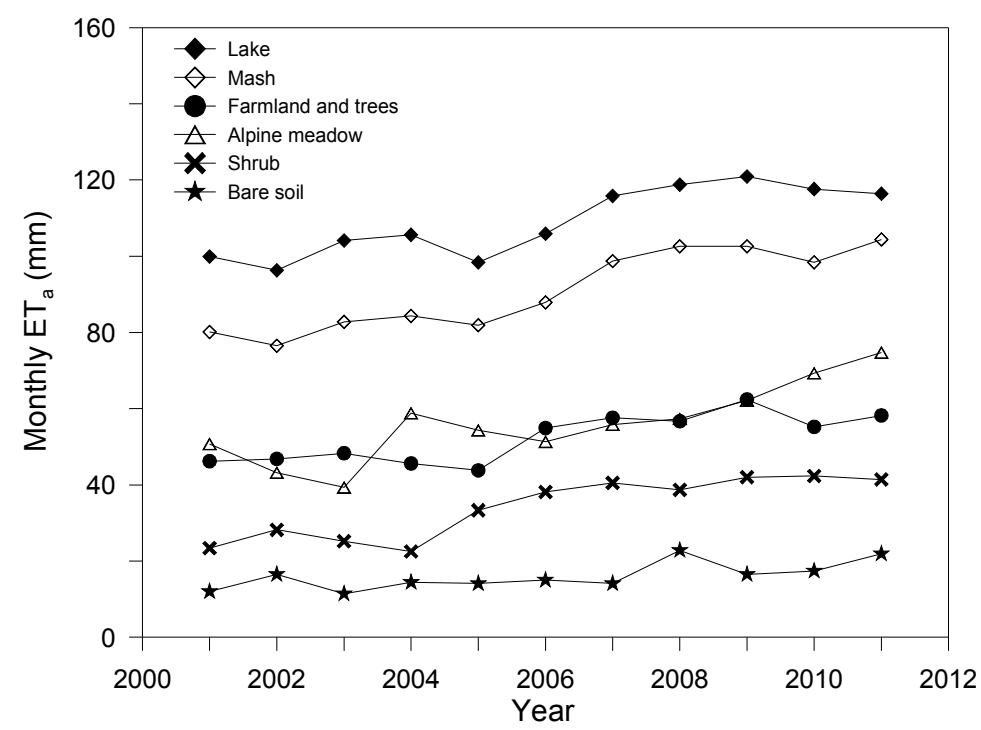

A section across different land cover types from north to south in the basin was selected to present and validate the $\mathrm{ET}_{\mathrm{a}}$ variation (Figure 11).

Figure 11. Section of monthly $\mathrm{ET}_{\mathrm{a}}$ variation for different land cover types.

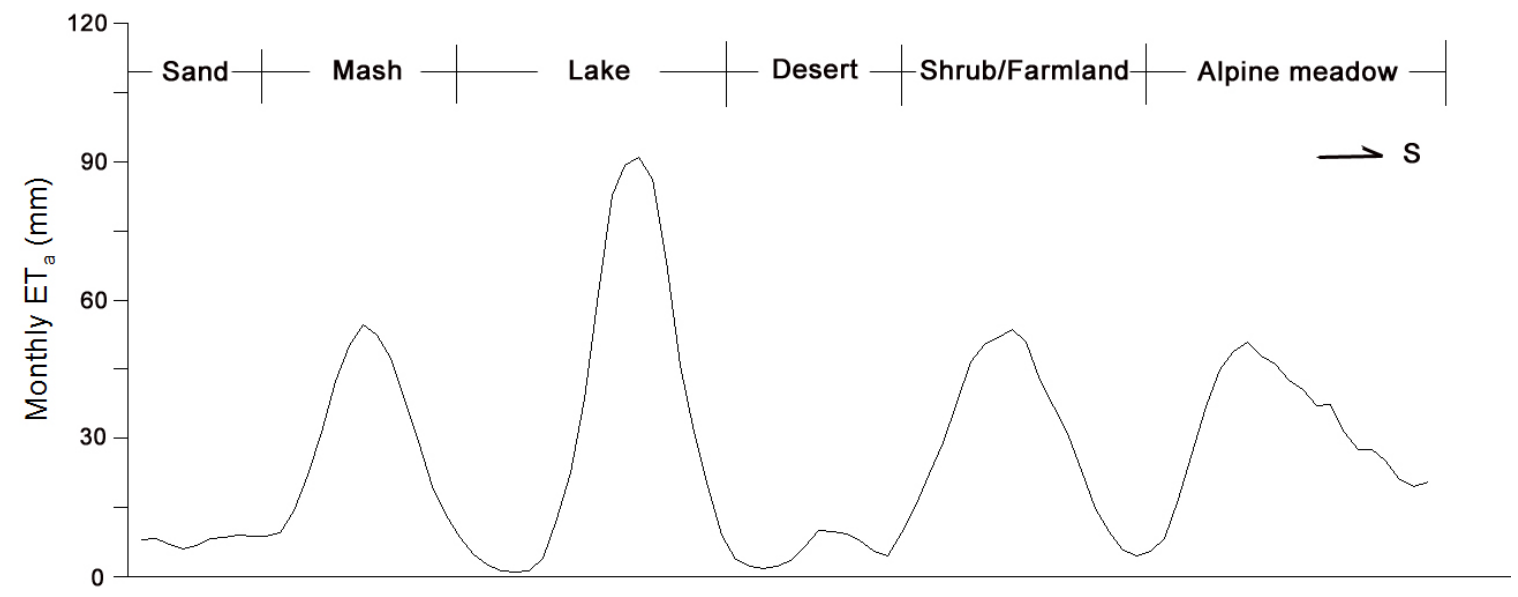

The two figures (Figure 10 and 11) also showed that water bodies have a higher mean actual evapotranspiration than expected and this can be explained by high moisture availability for water 
bodies. In terms of the relationship between areal coverage of land cover type and monthly $\mathrm{SEBS} \mathrm{ET}_{\mathrm{a}}$, the small land covered areas have higher mean actual evapotranspiration. Water bodies covering 1.5\% of the basin have a higher mean monthly actual evapotranspiration than $110 \mathrm{~mm}$. Mosaic of trees/farmlands and marsh that covered $1.1 \%$ and $0.9 \%$ of the basin also have relatively high mean actual evapotranspiration rates of $52 \mathrm{~mm}$ and $90 \mathrm{~mm}$, respectively. On the contrary, land cover types that covered large parts of the basin have low mean daily actual evapotranspiration. Bare soil has lowest monthly actual evapotranspiration of $15 \mathrm{~mm}$ but the land cover type covered $59.5 \%$ of Qaidam Basin. Shrubs covered $24.1 \%$ of the basin has relatively low mean monthly actual evapotranspiration rates of $34 \mathrm{~mm}$.

\subsection{Water Table Depth and Actual SEBS Evapotranspiration}

The scatter plots $\mathrm{ET}_{\mathrm{a}}$ against water table depth are presented in Figure 12, and the red line refers to the variation of average daily $\mathrm{ET}_{\mathrm{a}}$ with water table depth. In Figure 12a, daily $\mathrm{ET}_{\mathrm{a}}$ values vary between 0 and $3 \mathrm{~mm}$ and water table depth range from 0 to $3 \mathrm{~m}$, a dark cloud of data points concentrate in the area of $1 \mathrm{~m}<$ water table depth $<2 \mathrm{~m}$. There is declining trend of daily $\mathrm{ET}_{\mathrm{a}}$ with increasing water table depth. This agrees well with field investigation: in the WTM area where groundwater is shallow, the density of shrubs is larger, and more than $90 \%$ of the WTM area is covered by shrubs dominated by $P$. australis. The root zone of $P$. australis is shallow (less than $2 \mathrm{~m}$ ) and the shrub is highly dependent on soil water near the land surface. The average peak value of $\mathrm{ET}_{\mathrm{a}}$ is $1.5 \mathrm{~mm} \cdot \mathrm{d}^{-1}$ and the groundwater depth of $1.2 \mathrm{~m}$ corresponded to the $P$. australis. The average $\mathrm{ET}_{\mathrm{a}}$ decreases gradually when the groundwater depth is greater than $1.5 \mathrm{~m}$ and the mean $\mathrm{ET}_{\mathrm{a}}$ of this area is $1.3 \mathrm{~mm} \cdot \mathrm{d}^{-1}$.

Figure 12. The scatter plot of daily $\mathrm{ET}_{\mathrm{a}}$ against water table depth in (a) WTM and (b) DXS in June 2011.

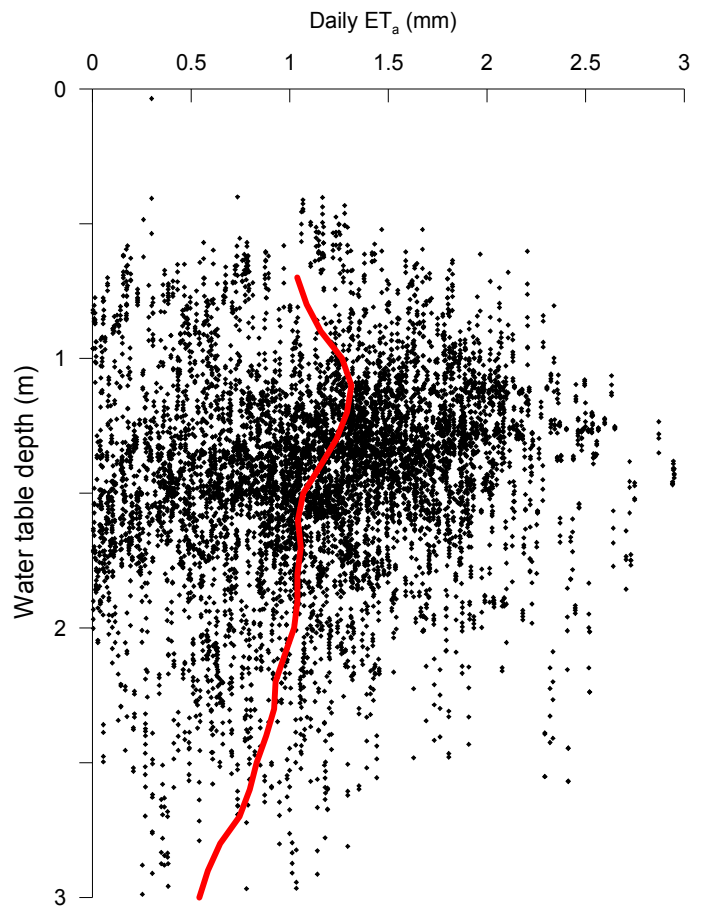

(a)

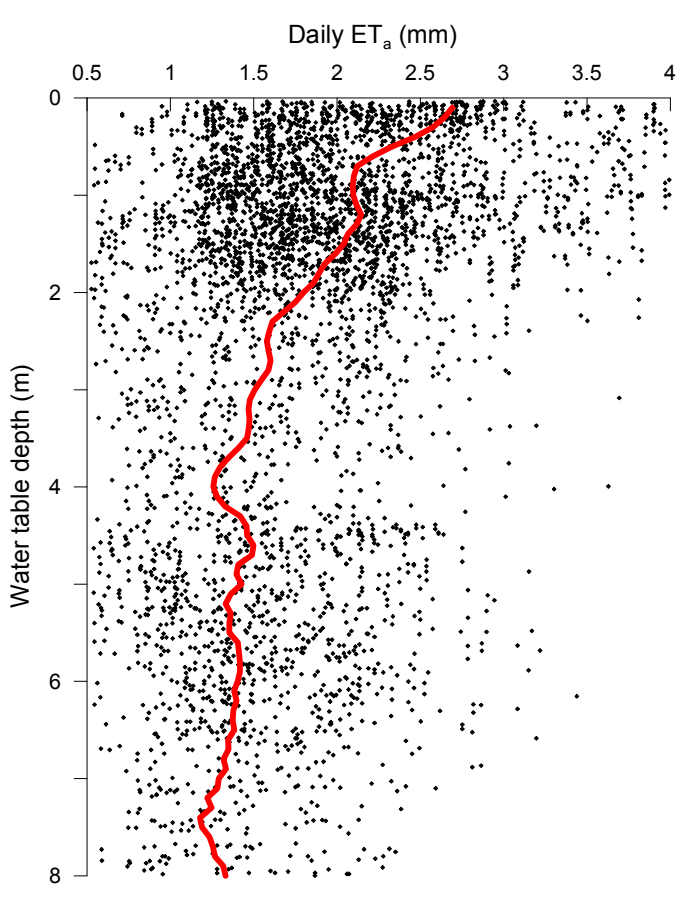

(b) 
The relationship between $\mathrm{ET}_{\mathrm{a}}$ and water table depth in DXS area is more complex because this zone is a mixture of farmlands and shrub lands. Two dark clouds of data point concentration occur: one at the water table depth between 0 and $2 \mathrm{~m}$ and another between 4 and $7 \mathrm{~m}$. The first may correspond to the farmland. The crops are irrigated and have higher $\mathrm{ET}_{\mathrm{a}}$ values. The second cloud of data may reflect on shrubs dominated by $A$. desertorum. The average $\mathrm{ET}_{\mathrm{a}}$ is in declining trend with increasing groundwater depth. However, the average $\mathrm{ET}_{\mathrm{a}}$ varies little when the water table depth is larger than $4 \mathrm{~m}$ and the value is around $1.5 \mathrm{~mm} \cdot \mathrm{d}^{-1}$ which is close to the mean daily $\mathrm{ET}_{\mathrm{a}}$ of DXS area. Since the recharge of groundwater is small, the $\mathrm{ET}_{\mathrm{a}}$ mainly comes from soil water in the areas of water table depth larger than $4 \mathrm{~m}$. It is deduced that the threshold depth of groundwater evaporation of the rainy season in the DXS area is about $4 \mathrm{~m}$. The surface ET is roughly equal to soil water evaporation $\left(1.5 \mathrm{~mm} \cdot \mathrm{d}^{-1}\right)$ when the groundwater depth is larger than $4 \mathrm{~m}$.

\section{Conclusions}

The Surface Energy Balance System (SEBS) algorithm was used in this research to estimate spatial actual evapotranspiration in Qaidam Basin and its eight hydrological sub-regions. In general, the actual evapotranspiration of east part was higher than west part of the basin. SEBS actual evapotranspiration estimates were evaluated in two stations and it was on average $7.5 \%$ and $14.1 \%$ of observed pan evaporation in west and east areas respectively. It was discussed that the difference could be due to variation of precipitation, temperature, roughness and heterogeneity parameters.

In terms of controlling factors, the east area was observed to be high actual evapotranspiration was discussed to be due the high vegetation coverage and precipitation. It was indicated that the land cover types with high evapotranspiration were water bodies, marsh and trees/farmland. These three land cover types covered less than $3.5 \%$ of the basin. Land cover types with lower evaporative behavior were sparse shrubs and bare soil, they covered almost $84 \%$ of the total study area. The impact of water table depth on actual evapotranspiration is more complex. Generally, the actual evapotranspiration is decreased with increase of water table depth.

Overall, SEBS was proved to be a useful tool for estimation of actual evapotranspiration in basin area. The SEBS actual evapotranspiration can be very helpful for regional hydrological assessment, water resources management and planning in arid and semi-arid areas. However, the more incisive analysis of effect of water table depth on actual evapotranspiration is needed in the near future.

\section{Acknowledgments}

This study is supported by the National Natural Science Foundation and Fundamental Research Funds for the Central Universities granted by the Ministry of Education of China. The authors also would like to acknowledge the IGIT project for the help in this study. Finally, we would like to thank the anonymous reviewers for their insightful and constructive comments.

\section{Conflicts of Interest}

The authors declare no conflict of interest. 


\section{References}

1. Sun, R.; Gao, X.; Liu, C.-M.; Li, X.-W. Evapotranspiration estimation in the Yellow River Basin, China using integrated NDVI data. Int. J. Remote Sens. 2004, 10, 2523-2534.

2. Glenn, E.P.; Huete, A.R.; Nagler, P.L.; Hirschboeck, K.K.; Brown, P. Review: Integrating remote sensing and ground methods to estimate evapotranspiration. Crit. Rev. Plant Sci. 2007, 26, 139-168.

3. Yang, D.; Chen, H.; Lei, H. Estimation of evapotranspiration using a remote sensing model over agricultural land in the North China Plain. Int. J. Remote Sens. 2010, 31, 3783-3798.

4. Rwasoka, D.T.; Gumindoga, W.; Gwenzi, J. Estimation of actual evapotranspiration using the surface Energy Balance System(SEBS) algorithm in the Upper Manyame catchment in Zimbabwe. Phys. Chem. Earth 2011, 36, 736-746.

5. Nagler, P.L.; Glenn, E.P.; Nguyen, U.; Scott, R.L.; Doody, T. Estimation riparian and agricultural actual evapotranspiration by reference evapotranspiration and MODIS enhanced vegetation index. Remote Sens. 2013, 5, 3849-3871.

6. Brown, K.W.; Rosenberg, N.J. A resistance model to predict evapotranspiration and its application to a sugar beet field. Agron. J. 1973, 65, 341-347.

7. Kite, G.W.; Pietroniro, A. Remote sensing application in hydrological modeling. Hydrol. Sci. 1996, 41, 563-591.

8. Rango, A.; Shalaby, A.I. Urgent Operational Applications of Remote Sensing in Hydrology. In Operational Hydrology Report 43; World Meteorology Organization: Geneva, Switzerland, 1999.

9. Sobrino, J.A.; Gómez, M.; Jiménez-muñoz, J.C.; Olioso, A. Application of a simple algorithm to estimate daily evapotranspiration from NOAA-AVHRR images for the Iberian Peninsula. Remote Sens. Environ. 2007, 110, 139-148.

10. Morse, A.; Tasumi, M.; Allen, R.G.; Kramber, W.J. Application of the SEBAL Methodology for Estimating Consumptive Use of Water and Stream Flow Depletion in the Bear River Basin of Idaho through Remote Sensing. In The Raytheon Systems Company-Earth Observation System Data and Information System Project; The Raytheon Systems Company: Idaho Falls, ID, USA, 2000; pp. 107.

11. Menenti, M.; Choudhury, B.J. Parametrization of Land Surface Evapotranspiration Using a Location Dependent Potential Evapotranspiration and Surface Temperature Range. In Exchange Processes at the Land Surface for a Range of Space and Time Scales; Bolle, H.J., Ed.; IAHS: Wallingford, CT, USA, 1993; pp. 561-588.

12. Norman, J.M.; Kustas, W.P.; Humes, K.S. A two-source approach for estimating soil and vegetation energy fluxes in observations of directional radiometric surface temperature. Agricult. For. Meteorol. 1995, 77, 263-293.

13. Bastiaanssen, W.G.M.; Ahmed, M.; Chemin, Y. Satellite surveillance of evaporative depletion across the Indus Basin. Water Resour. Res. 2002, 38, 1273-1282.

14. Roerink, G.J.; Su, Z.; Menenti, M. S-SEBI: A simple remote sensing algorithm to estimate the surface energy balance. Phys. Chem. Earth B 2000, 25, 147-157.

15. Su, Z. The Surface Energy Balance System (SEBS) for estimation of turbulent heat fluxes. Hydrol. Earth Syst. Sci. 2002, 6, 85-99. 
16. Gowda, P.H.; Chavez, J.L.; Colaizzi, P.D.; Evett, S.R.; Howell, T.A.; Tolk, J.A. Remote sensing based energy balance algorithms for mapping ET. Trans. ASABE 2007, 50, 1639-1644.

17. Kalma, J.D.; Mcvicar, T.R.; McCabe, M.F. Estimating land surface evaporation: A review of methods using remotely sensed surface temperature data. Surv. Geophys. 2008, 29, 421-469.

18. Kustas, W.; Anderson, M. Advances in thermal infrared remote sensing for land surface modeling. Agric. For. Meteorol. 2009, 149, 2071-2081.

19. Bastiaanssen, W.G.M.; Menenti, M.; Feddes, R.A.; Holtslag, A.A.M. A remote sensing surface energy balance algorithm for land (SEBAL). 1. Formulation. J. Hydrol. 1998, 212-213, 198-212.

20. Allen, R.G.; Tasumi, M.; Trezza, R. Satellite-based energy balance for mapping evapotranspiration with internalized calibration (METRIC)-Model. J. Irrig. Drain. Eng. 2007, 133, 380-394.

21. Sun, J.; Salvucci, G.D.; Entekhabi, D.; Farhadi, L. Parameter estimation of coupled water and energy balance models based on stationary constraints of surface states. Water Resour. Res. 2011, 47, W02512.

22. Sun, J.; Salvucci, G.D.; Entekhabi, D. Estimates of evapotranspiration from MODIS and AMSR-E land surface temperature and moisture over the Southern Great Plains. Remote Sens. Environ. 2012, 127, 44-59.

23. Kustas, W.P.; Norman, J.M. A two-source approach for estimating turbulent fluxes using multiple angle thermal infrared observations. Water Resour. Res. 1997, 33, 1495-1508.

24. Anderson, M.C.; Kustas, W.P.; Norman, J.M. Upscaling flux observations from local to continental scales using thermal remote sensing. Agron. J. 2007, 99, 240-254.

25. Su, Z.; Schmugge, T.; Kustas, W.P.; Massman, W.J. An evaluation of two models for estimation of roughness height for heat transfer between the land surface and atmosphere. J. Appl. Meteorol. 2001, 40, 1933-1951.

26. Melesse, A.M.; Nangia, V. Estimation of spatially distributed surface energy fluxes using remotely-sensed data for agricultural fields. Hydrol. Process. 2005, 19, 2653-2670.

27. Melesse, A.M.; Frank, A.; Nangia, V.; Hanson, J. Analysis of energy fluxes and land surface parameters in a grassland ecosystem: A remote sensing perspective. Int. J. Remote Sens. 2008, 29, 3325-3341.

28. Senay, G.B.; Budde, M.; Verdin, J.P.; Melesse, A.M. A coupled remote sensing and simplified energy balance approach to estimate actual evapotranspiration from irrigated fields. Sensors $\mathbf{2 0 0 7}$ 7, 979-1000.

29. Melesse, A.M.; Oberg, J.; Nangia, V.; Beeri, O.; Baumgartner, D. Spatiotemporal dynamics of evapotranspiration at the Glacial Ridge prairie restoration in northwestern Minnesota. Hydrol. Process. 2006, 20, 1451-1464.

30. Kustas, W.P.; Anderson, M.C.; Norman, J.M.; Li, F. Utility of radiometric-Aerodynamic temperature relations for heat flux estimation. Bound.-Layer Meteorol. 2007, 122, 167-187.

31. Melesse, A.M.; Abtew, W.; Dessalegne, T. Evaporation estimation of Rift Valley Lakes: Comparison of models. Sensors 2009, 9, 9603-9615.

32. Gokmen, M.; Vekerdy, Z.; Verhoef, A.; Verhoef, W.; Batelaan, O.; van der Tol, C. Integration of soil moisture in SEBS for improving evapotranspiration estimation under water stress conditions. Remote Sens. Environ. 2012, 121, 261-274. 
33. Jia, L.; Su, Z.; van Den Hurk, B.J.J.M.; Menenti, M.; Moene, A.R.; de Bruin, H.A.R.; Yrisarry, J.J.B.; Ibanez, M.; Cuesta, A. Estimation of sensible heat flux using the surface energy balance system SEBS and ATSR measurements. Phys. Chem. Earth 2003, 28, 75-88.

34. Ma, Y.; Song, M.; Ishikawa, H.; Yang, K.; Koike, T.; Jia, L.; Menenti, M.; Su, Z. Estimation of the regional evaporative fraction over the Tibetan plateau area by using Landsat-7 ETM data and the field observations. J. Meteorol. Soc. Jpn. 2007, 85A, 295-309.

35. Jin, X.M.; Schaepman, M.E.; Clevers, J.G.P.W.; Su, Z. Impact and consequences of evapotranspiration changes on water resources availability in the arid Zhangye Basin, China. Int. J. Remote Sens. 2009, 30, 3223-3238.

36. Su, Z.; Pelgrum, H.; Menenti, M. Aggregation effects of surface heterogeneity in land surface processes. Hydrol. Earth Syst. Sci. 1999, 3, 549-563.

37. Kustas, W.P.; Daughtry, C.S.T. Estimation of the soil heat flux/net radiation ratio from spectral data. Agric. For. Meteorol. 1989, 49, 205-223.

38. Monteith, J.L. Principles of Environmental Physics; Edward Arnold: London, UK, 1973.

39. Van der Kwast, J.; Timmermans, W.; Gieske, A.; Su, Z.; Olioso, A.; Jia, L.; Elbers, J.; Karssenberg, D.; de Jong, S. Evaluation of the Surface Energy Balance System (SEBS) applied to ASTER imagery with flux-measurements at the SPARC 2004 site (Barrax, Spain). Hydrol. Earth Syst. Sci. 2009, 13, 1337-1347.

40. Brutsaert, W. Evaporation into the Atmosphere: Theory, History, and Applications; Reidel Publishing: Dordrecht, The Netherlands, 1982.

41. Jin, S; Sader, S.A. MODIS time-series imagery for forest disturbance detection and quantification of patch size effects. Remote Sens. Environ. 2005, 99, 462-470.

42. Sakamoto, T.; Yokozawa, M.; Toritani, H.; Shibayama, M.; Ishitsuka, N.; Ohno, H. A crop phenology detection method using time-series MODIS data. Remote Sens. Environ. 2005, 96, 366-374.

43. Knight, J.K.; Lunetta, R.L.; Ediriwickrema, J.; Khorram, S. Regional Scale Land-Cover Characterization using MODIS-NDVI 250m multi-temporal imagery: A phenology based approach. GISci. Remote Sens. 2006, 43, 1-23.

44. Lunetta, R.S.; Knight, J.F.; Ediriwickrema, J.; Lyon, J.G.; Worthy, L.D. Landcover change detection using multi-temporal MODIS NDVI data. Remote Sens. Environ. 2006, 105, 142-154.

45. Wardlow, B.D.; Egbert, S.L.; Kastens, J.H. Analysis of time-series MODIS 250 m vegetation index data for crop classification in the US Central Great Plains. Remote Sens. Environ. 2007, 108, 290-310.

46. Caccamo, G.; Chisholm, L.A.; Bradstock, R.A.; Puotinen, M.L. Assessing the sensitivity of MODIS to monitor drought in high biomass ecosystems. Remote Sens. Environ. 2011, 115, 2626-2639.

47. Hwang, T.; Song, C.; Bolstad, P.V.; Band, L.E. Downscaling real-time vegetation dynamics by fusing multi-temporal MODIS and Landsat NDVI in topographically complex terrain. Remote Sens. Environ. 2011, 115, 2499-2512.

48. Le Marie, G.; Marsden, C.; Verhoef, W.; Ponzoni, F.J.; Seen, D.L.; Bégué, A.; Stape, J.L.; Nouvellon, Y. Leaf area index estimation with MODIS reflectance time series and model inversion during full rotations of Eucalyptus plantation. Remote Sens. Environ. 2011, 115, 586-599. 
49. Kumar, S.V.; Peters-Lidard, C.D.; Tian, Y.; Houser, P.R.; Geiger, J.; Olden, S.; Lighty, L.; Eastman, J.L.; Doty, B.; Dirmeyer, P.; et al. Land Information System-An interoperable framework for high resolution land surface modeling. Environ. Model. Softw. 2006, 21, 1402-1415.

50. Badola, A. Validation of Surface Balance Systems SEBS over Forest Land Cover and Sensitivity Analysis of the Model. Master Thesis, Faculty of Geo-Information and Earth Observation (ITC), University of Twente, Enschede, The Netherlands, 2009.

(C) 2013 by the authors; licensee MDPI, Basel, Switzerland. This article is an open access article distributed under the terms and conditions of the Creative Commons Attribution license (http://creativecommons.org/licenses/by/3.0/). 